原著

\author{
筋強直性ジストロフィー 1 型の遺伝学的診療に関する \\ 臨床遺伝専門医対象調查
}

松村 剛1)* 秋澤 叔香2) 石垣 景子 3) 高橋 $\quad$ 正紀4)

\begin{abstract}
要旨: 筋強直性ジストロフィー 1 型の遺伝学的診療について, 臨床遺伝専門医を対象に調査を行った. 患者自 身の課題への対応は, 診療科による違いや中枢神経障害の影響が見られた. 出生前診断 (prenatal diagnosis, 以 下 PND と略記) ・着床前診断（preimplantation genetic testing, 以下 PGT と略記）については, 男性も対象, 男 性のPND に対応している, PGT の基準を緩めるべきとの回答が予想より多かった. このため, 全国遺伝子医療 部門参加施設に実施状況を調査した. 男性患者で PND・PGT を実施した施設は無かったが, PGT 申請中が 1 施 設あった. 生殖医療の社会的コンセンサスは，技術進歩や時代背景の影響を受ける. 優生思想を排除した上で, 当事者を含む多分野が参加した協議によるコンセンサス形成が重要である.
\end{abstract}

(臨床神経 2021;00:000-000)

Key words : 筋強直性ジストロフィー 1 型, 遺伝学的診療, 臨床遺伝専門医, 出生前診断, 着床前診断

\section{前文}

筋強直性ジストロフィー 1 型 (dystrophia myotonica type 1, 以下 DM1 と略記）は, 筋強直現象や筋力低下に加え, 多彩 な合併症を有する常染色体優性遺伝形式の疾患である ${ }^{1) ~ 3)}$. DM1 protein kinase (DMPK) の CTG 繰返し配列が, 50 回以 上に延長することで生じ, 親世代よりも子世代で若年発症 · 重症化する傾向（表現促進現象）が見られる. 女性患者では, 出生時から重篤な症状を呈する先天性筋強直性ジストロ フィー (congenital myotonic dystrophy, 以下 CDM と略記) が生じることが多い 1) 3) 一方, 男性患者から CDM が生じる ことは稀である。

DM1 では治療開発が進みつつあり, 確定診断は治療選択や 合併症管理の上で重要な意味を持つ。他方，次世代への影響 に性差があり，家族計画や生殖医療への配慮が必要など，本 症の遺伝学的診療には課題も多い.われわれは「筋強直性ジ ストロフィー診療ガイドライン $2020 」 を 2020$ 年 9 月に刊行
したが, DM1 における遺伝学的診療の現状を把握する必要を 感じたため, 臨床遺伝専門医（Clinical Genetic Specialist，以 下 CGS と略記) および全国遺伝子医療部門連絡会議（以下遺 伝子医療部門）参加施設を対象としたアンケート調査を実施 した。

\section{対象・方法}

\section{CGS 対象調査}

2020 年 1 月時点の CGS 1,444 名を対象に, 2020 年 4 6 月 を調査期間として Web または郵送回答による無記名アンケー トを実施した（Supplement 1).プロフィール項目は全員に, 遺伝学的設問は DM 患者の遺伝学的診療に 1 年以内に携わっ た（Present）CGS と，過去に経験がある（Past）または未経 験（None）で回答を承諾したCGSに協力いただいた。

\footnotetext{
*Corresponding author: 国立病院機構大阪刀根山医療センター脳神経内科〔⿳ 560-8552 大阪府豊中市刀根山 5-1-1〕

1) 国立病院機構大阪刀根山医療センター脳神経内科

2) 東京女子医科大学産科婦人科

3) 東京女子医科大学小児科

4) 大阪大学大学院医学系研究科保健学専攻機能診断学講座

(Received February 16, 2021; Accepted March 24, 2021; Published online in J-STAGE on August 26, 2021) doi: 10.5692/clinicalneurol.cn-001605
}

Supplementary data for this article is available in our online journal. Official Website http://www.neurology-jp.org/Journal/cgi-bin/journal.cgi J-STAGE https://www.jstage.jst.go.jp/browse/clinicalneurol 
2. 遺伝子医療部門参加施設対象調査

出生前診断 (prenatal diagnosis, 以下 PND と略記), 着床 前診断 (preimplantation genetic testing, 以下 PGT と略記) の実施状況を確認する目的で, 2020 年 10 月時点の遺伝子医 療部門参加 131 施設に, 2020 年 11〜12 月を調査期間として, 男性・女性毎の PND - PGT 実施有無, 有りの場合は直近 3 年 間の実施症例数, 自由記載で DM1 での PND・PGT に対する 意見について，無記名アンケートを実施した (Supplement 2).

両調査は国立病院機構大阪刀根山医療センター臨床研究審 査委員会にて承認（TNH-2019047: 2020 年 1 月 17 日承認, TNH-R-2020045: 2020 年 11 月 20 日承認）を得て実施した.

\section{3. 統計学的解析}

SSPS ver.27 を用い，群間比較は $\chi^{2}$ 検定で行った。専門領 域は脳神経内科 (Neurology, 以下 $\mathrm{N}$ と略記)，小児神経科 (Pediatric Neurology, 以下 PN と略記), 小览科 (Pediatrics, 以下 $\mathrm{P}$ と略記)，産婦人科 (Obstetrics and Gynecology, 以下 OG と略記)，遺伝診療科（Medical Genetics，以下 MG と略 記), それ以外 (Others) に区分した. 施設は大学病院 (Academic Medical Center, 以下 AMC と略記), 総合病院 (General Hospital，以下 GH と略記），国立病院機構（National Hospital Organization, 以下 NHO と略記), その他 (Others) に分けた.

\section{結果}

\section{CGS 対象調查}

617 名（回収率 44.6\%) から回答を得た. 31 名は同意チェッ クが無く，解析対象は 586 名とした（Fig. 1)。所属施設は AMC 274 名, GH 148 名, NHO 58 名, Others 106 名, 診療科 は N 57 名, PN 55 名, P 130 名, OG 221 名, MG 28 名, Others 95 名, 診療経験は Present 161 名, Past 169 名, None 256 名 で，362 名が遺伝学的設問に回答した（Supplement 3).

i. 遺伝学的診療を依頼された場合の対応（単一選択，回答者 581 名)

「専門家の協力があれば対応」 $42.7 \%$,「自身で対応」30.8\%，

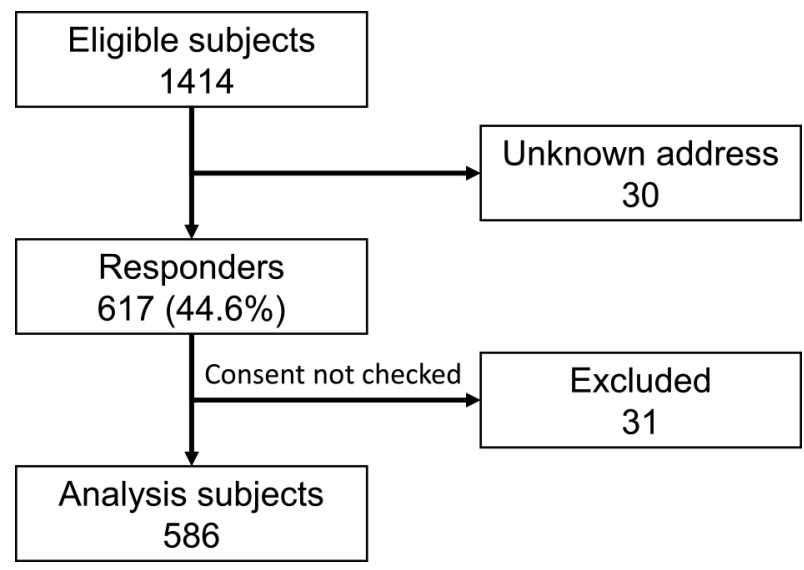

Fig. 1 Subjects.
「他の医師に紹介する」 $26.5 \%$ たっった。 OGでは「専門家の協 力があれば対応」が $57.5 \%$ 占めた。

ii. 発症者の確定診断時に行う説明（複数選択, 回答者 366 名) 「遺伝学的検査の有益性/問題点」95.1\%，「家系の情報とな る」91.8\%，「文書同意取得」 $81.7 \%$,「PND・PGTに必要な 情報となる」 $72.7 \%$, 「新規治療の適応条件になる場合があ る」35.5\%であった。「PND・PGT に必要な情報となる」は， OG, Present で 8 割を超え,「新規治療の適応条件になる場合 がある」は, PN, N で 5 割以上, MG, NHO, Present で 4 割以上だった（Fig. 2).

iii. 確定診断時のアトリスク血縁者（非発症者）に対する説 明（単一選択，回答者 362 名）

「原則的に行う」 $68.5 \%$,「状況によって行う」 $28.2 \%$ ，「行っ ていない」3.0\%で, 診療科や施設, 診療経験による有意な差 はなかったが，「原則的に行う」は MG で 8 割以上と高い傾 向であった。

iv. 成人アトリスク非発症者の確定診断に対する考え（複数 選択，回答者 359 名）

「非発症者の確定診断はすべきでない」は $11.7 \%$ だけで, 「合併症の早期発見・治療のために実施しても良い」 $66.9 \%$, 「運動機能障害に備えるために実施しても良い」48.7\%，「治 療機会保証のために実施しても良い」41.5\%，「女性で挙児希 望があれば実施しても良い」55.4\%，「男性で挙児希望があれ ば実施しても良い」30.6\%だった，PN，Pでは「合併症の早 期発見・治療のために実施しても良い」が 7 割以上だった が，Nと NHO は他に比べ「合併症の早期発見・治療のため に実施しても良い」,「運動機能障害に備えるために実施して も良い」が低く，「非発症者の確定診断はすべきでない」が高 かった。「女性で挙児希望があれば実施しても良い」，「男性で 挙児希望があれば実施しても良い」，は診療科や施設による 差は認めなかったが, Present が $62.9 \%, 37.1 \%$ と高かった (Fig. 3).

v. 判断能力が不十分なアトリスク非発症者の確定診断に対す る考え（複数選択，回答者 361 名）

「未成年者は本人の判断能力が備わるまで待つ」 $66.2 \%$,「判 断能力獲得が期待できない場合は保護者・代諾者の承諾で実 施しても良い」31.0\%，「保護者・代諾者が希望してもすべき でない」29.6\%，「保護者・代諾者が希望すれば実施しても良 い」10.0\%の順であった。また，「合併症の早期発見・運動機 能障害への対応のため実施しても良い」 $22.2 \%$,「治療機会保 証のために実施しても良い」16.9\%であった，診療科や施設， 診療経験による有意差はなかったが，PNは「保護者・代諾 者が希望すれば実施しても良い」18.8\%，「合併症の早期発 見・運動機能障害への対応のため実施しても良い」35.4\%, 「治療機会保証のために実施しても良い」 $29.2 \%$ が他科より高 かった (Fig. 4).

vi. 確定診断時の説明（複数選択，回答者 360 名）

「常染色体優性遺伝，妊娠前の遺伝相談の必要性」 $88.1 \%$, 「運動機能障害」 $85.6 \%$ ，「専門医療機関への定期受診指導」 $83.1 \%$ ，「表現促進現象」 $81.9 \%$ ，「指定難病や身体障害等の 


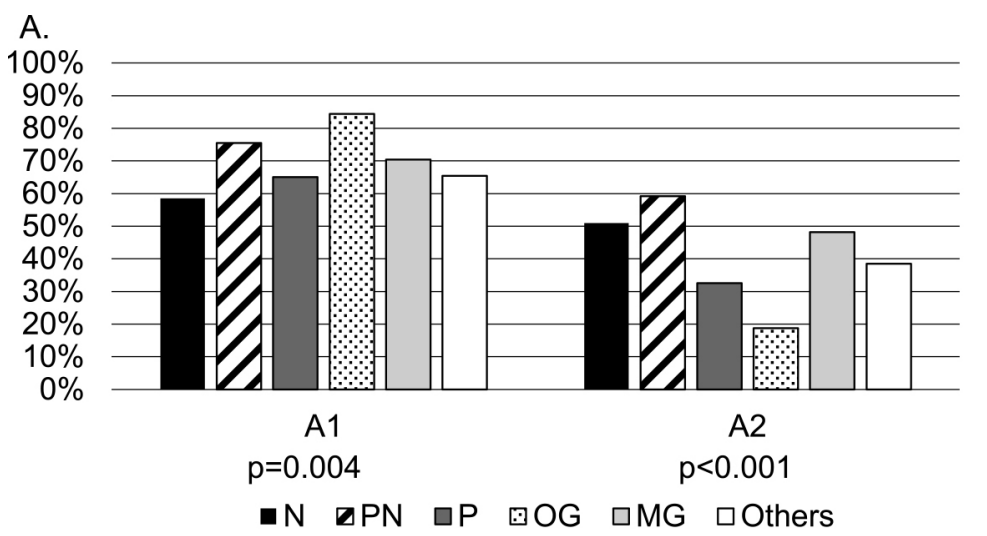

B.

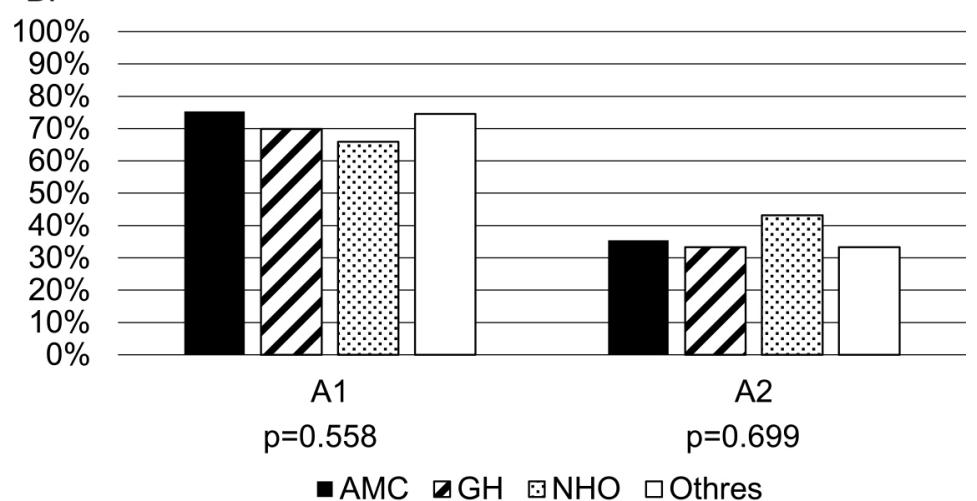

C.

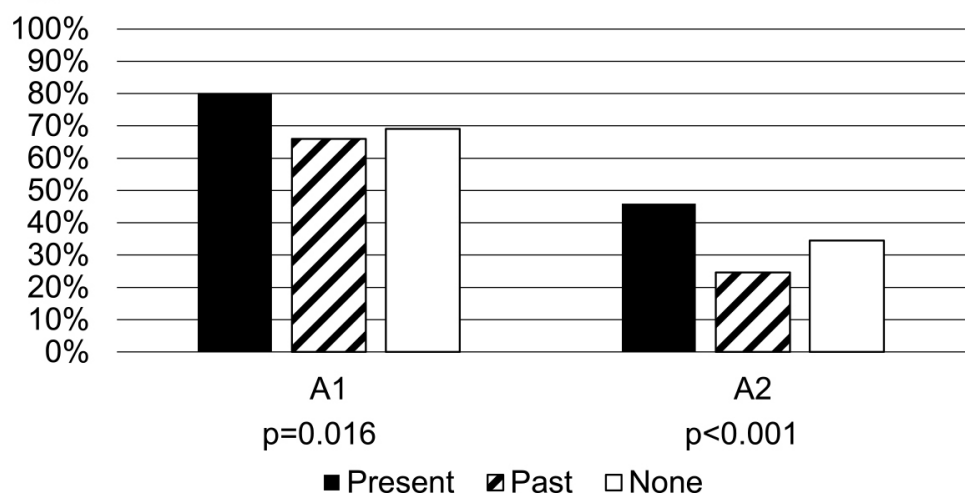

Fig. 2 Explanation for genetic diagnosis for affected patients.

A. Comparison among specialities, B. Comparison among facilities, C. Comparison among experience of DM1.

A1. Explain that the information obtained is needed if the patients wish to proceed with prenatal diagnosis or preimplantation genetic diagnosis.

A2. Explain that the information obtained may be used as a criterion for participation in a clinical trial or treatment when a novel treatment is developed.

社会制度」 $70.60 \%, 「$ 多藏器障害」 $69.7 \%$,「突然死リスク」 $45.8 \%$,「患者登録」39.7\%,「特別な説明は行わない」0\%で あった.「常染色体優性遺伝, 妊娠前の遺伝相談の必要性」, 「専門医療機関への定期受診指導」「表現促進現象」について は, 診療科, 施設, 診療経験で差はなかったが, OGはそれ 以外の説明実施率が低かった（Fig. 5A）。AMC，NHO，遺伝 子医療部門施設, Present は, 「多臓器障害」, 「指定難病や身
体障害等の社会制度」,「患者登録」の説明実施率が高かった (Fig. 5B, C, D).

vii. 女性患者における PNDへの対応（単一回答, 回答者 362 名）

「遺伝カウンセリング (genetic counseling, 以下 GC と略 記) · PND 共に対応」 $30.4 \%, 「 \mathrm{GC}$ の対応」 $47.0 \%$,「PND のみ対応」 $0.8 \%$, 「他施設に依頼」 $8.8 \%, 「 \mathrm{PND} に は$ 対応し 

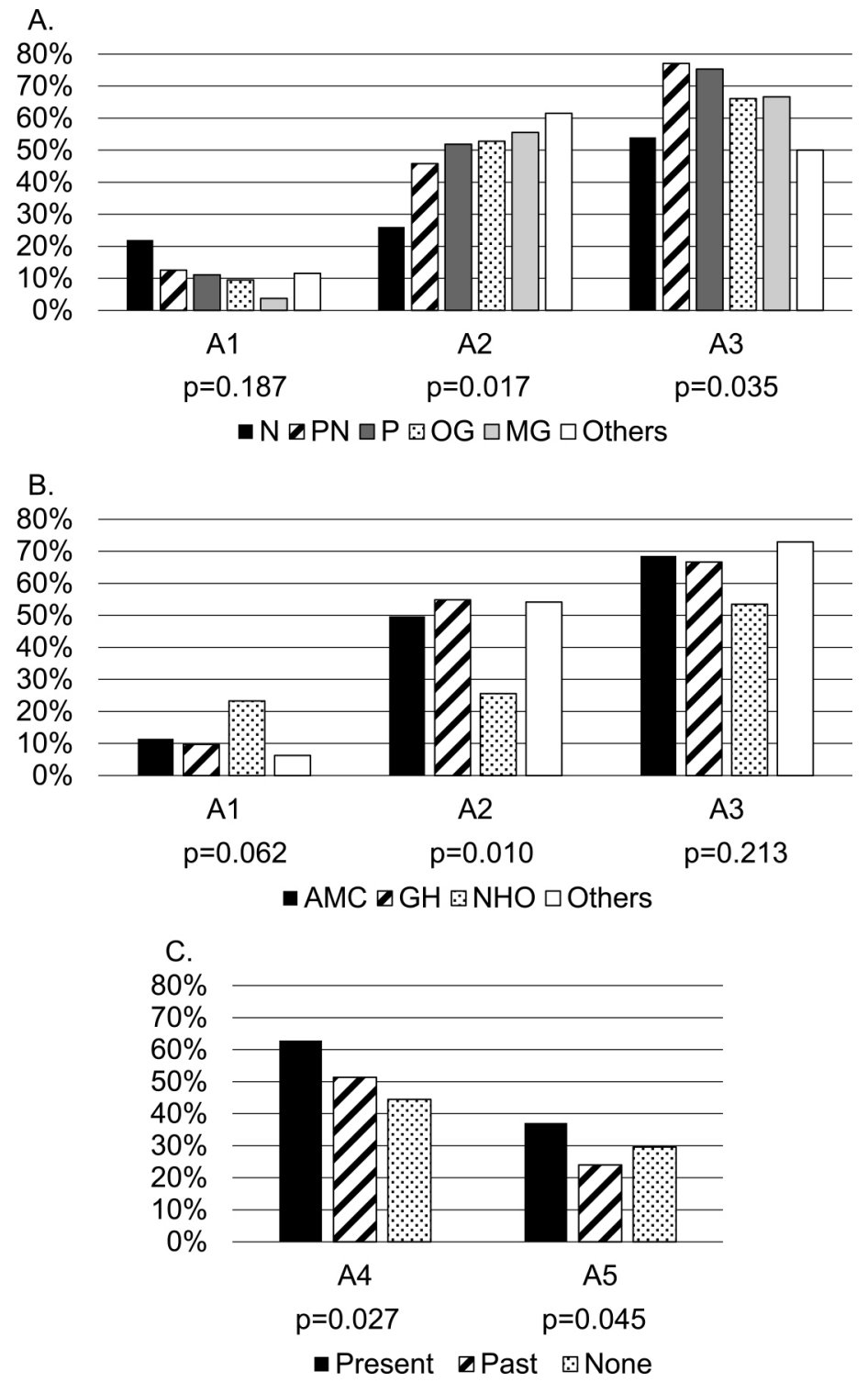

Fig. 3 Opnion for genetic diagnosis for at-risk but asymptomatic adult individuals.

A. Comparison among specialities, B. Comparison among facilities, C. Comparison among experience of DM1.

A1. Genetic diagnosis should not be performed for asymptomatic individuals.

A2. Genetic diagnosis may be performed to help them prepare for developing motor dysfunction.

A3. Genetic diagnosis may be performed to enable early detection and treatment of multiple organs complications.

A4. Genetic diagnosis may be performed for female individuals if they are planning to have children.

A5. Genetic diagnosis may be performed for male individuals if they are planning to have children.

ていない」 $13.0 \%$ であった。「GC・PND 共に対応」は OG, $\mathrm{AMC}$ ，遺伝子医療部門施設で 4 割を超えた。「GC のみ対応」 はN，PN，P，MG，Presentで 5 割以上だった（Fig. 6).

viii. 男性患者に㧈ける PNDへの対応（単一回答，回答者 331 名)

「男性も対象」が $67.1 \%$ 占め, OG で $77.6 \%$ と高かった 施設, 診療経験による有意差は無かった。「男性も対象」と回 答した者では,「GC・PND 共に対応」 $30.2 \%$,「GCのみ対 応」 $48.6 \%$,「PND のみ対応」 $2.3 \%$,「他施設に依頼」 $18.5 \%$
であった，OG，MG，AMC，遺伝子医療部門施設で「GC・ PND 共に対応」が 4 割以上だった（Fig. 7).

ix. PGT についての考元（単一回答，回答者 350 名）

「行うべきでない」は $13.4 \%$ ので,「基準を緩めて選択し やすくすべき」38.9\%，「男女とも対象」 $28.0 \%$,「女性のみ 対象」19.7\%であった。「行うべきでない」は MG, 遺伝子医 療部門施設, Present で低く,「女性のみ対象」は PN, MG, 遺伝子医療部門施設, Present で高い傾向だったが,「男女と も対象」を上回ったのはPNのみだった（Fig. 8). 


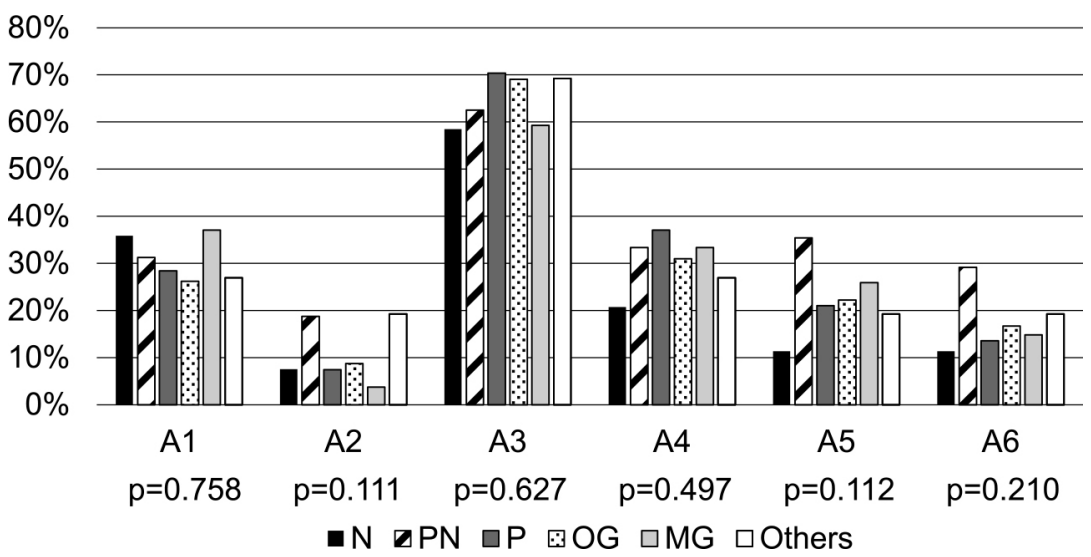

Fig. 4 Comparison among specialities about opinion for genetic diagnosis for at-risk but asymptomatic minor or mental retarded adult individuals.

A1. Genetic diagnosis should not be performed even if their parents or legal representatives wish to receive it.

A2. Genetic diagnosis may be performed if their parents or legal representative wish to receive it.

A3. Genteic diagnosis should be performed only after the individuals become old enough and gain the ability to make the judgement.

A4. Genetic diagnosis may be performed with approval from the parents or legal representatives if the individuals are not expected to gain the ability to make the judgement.

A5. Genetic diagnosis may be performed to enable early detection of multiple organs complications and to help them prepare for developing motor dysfunction.

A6. Genetic diagnosis may be performed to ensure that they have the opportunity to receive any treatments that may become available in the future.

X. 自由記載（回答者 66 名）

PND・PGT については慎重な意見もあったが,「他国でで きることは日本でもすべき」,「個別の検討が必要だが, 男性 も認めるべき」など積極的な意見が多く，「多学会合同でのガ イドライン作成」,「PND 可能な施設の情報提供」を求める意 見もあった。

妊娠・出産に関わる問題についても，「妊娠・周産期管理に 注意が必要」，「受容できないうちに出産を迎え，重篤な児を 見てパニックになることが多い」「妊娠前の診断が重要」,「パー トナー・家族へのサポートが重要」，「母親は自分の診療が後 回しになって自身の受診に結びつかないことが多い」など様々 な回答があった。

医療連携については,「遺伝子医療部門との連携が大切」, 「小児診療科で子供を診断した場合，親の診療を $\mathrm{N}$ に依頼し ている」など前向きな記載もあったが，「専門医がいない」, 「紹介先が見つからない」,「診断後の診療が途絶えている」な ど困難さを訴えるものも多かった。中枢神経障害に関連して, 「説明の理解が困難」,「家族歴があっても診断・受診の必要性 が理解されない」,「繰り返し説明を行っている」なども見ら れた。

新規治療開発への期待も多く,「治療薬の出現・開発状況に よって GC の内容・対応が変わる」との記載もあった。

\section{遺伝子医療部門参加施設対象調査}

77 施設（回答率 $58.8 \%$ ）から回答があり，全件同意チェッ
クされていた (Supplement 4). 女性患者の PND・PGT は 10 施設で実績が有り， 2 施設は両方， 5 施設は PNDのみ， 3 施 設はPGTのみ実施されていた。過去 3 年間の実績数はPND で 0 例が 1 施設, 1 例が 5 施設, 2 例が 1 施設, PGT は 1 例 が 4 施設, 2 例が 1 施設であった（Supplement 5). 男性患者 でPND・PGTの実績がある施設は無かったが, 1 施設で PGT 申請中だった。

自由記載では, 男性患者の PND・PGTに消極的意見が 6 施設あった一方で，当事者の希望を最優先すべき・男性も対 象など積極的回答が 10 施設あった。無規制での実施を防ぐ 上でも適切な GC ができる施設で受けられるようにすべき $(5$ 施設), PGTの方が PND より倫理的ハードルや患者負担が低 い（4 施設), PGT を利用しやすい環境にすべき（2 施設）, 男女とも慎重にすべき (2 施設), 表現促進現象に対する判断 が困難 (5 施設), 治療の出現により再検討が必要 (1 施設), 中枢神経障害のため判断力が低い場合がある $(2$ 施設 $)$, など の意見もあった。

\section{考察}

DM1 の遺伝学的診療では, 本人の課題（運動機能・合併症 への対応, 集学的管理) に加え, 家系や次世代の課題（優性 遺伝形式, 表現促進現象）に加え, 次世代への影響に性差が ある, 中枢神経障害により判断能力が不十分な患者が多いな ど多くの問題がある。また, 発症者で DM1を強く疑う場合 の遺伝学的検索では一般の脳神経内科 · 小巟神経科医で説 


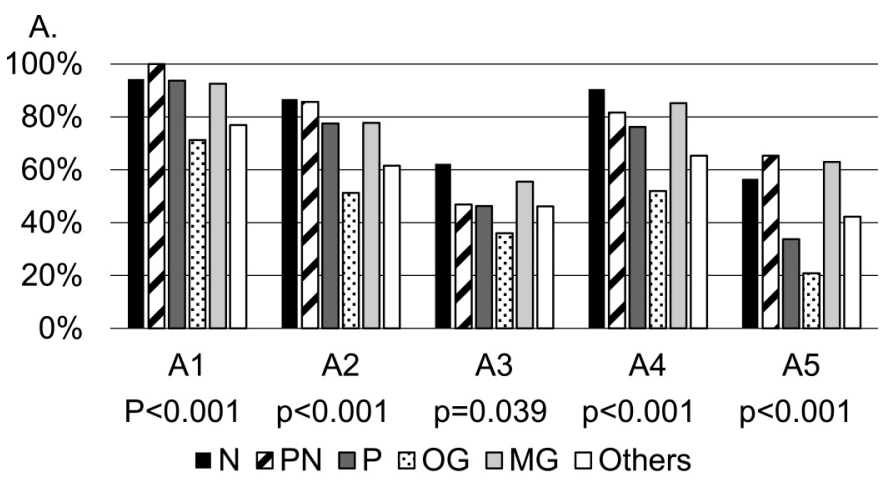

B.

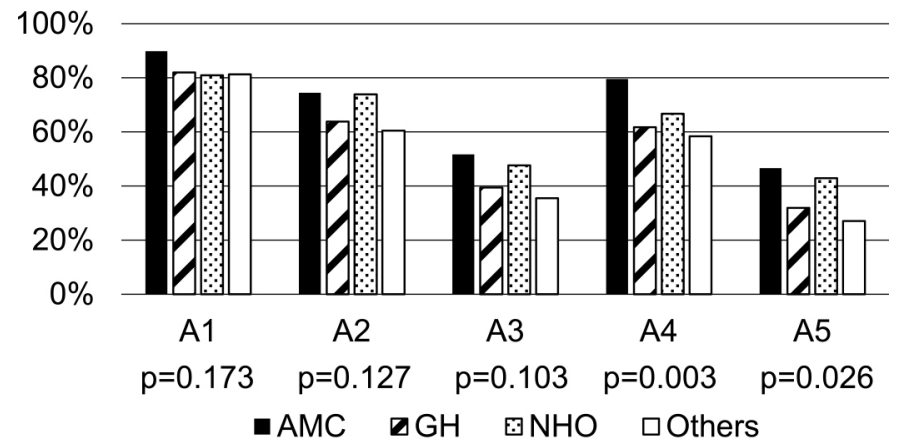

C.

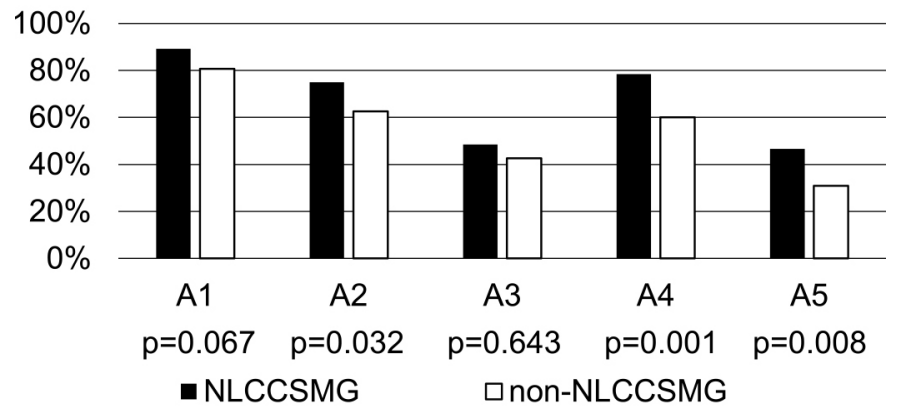

D.

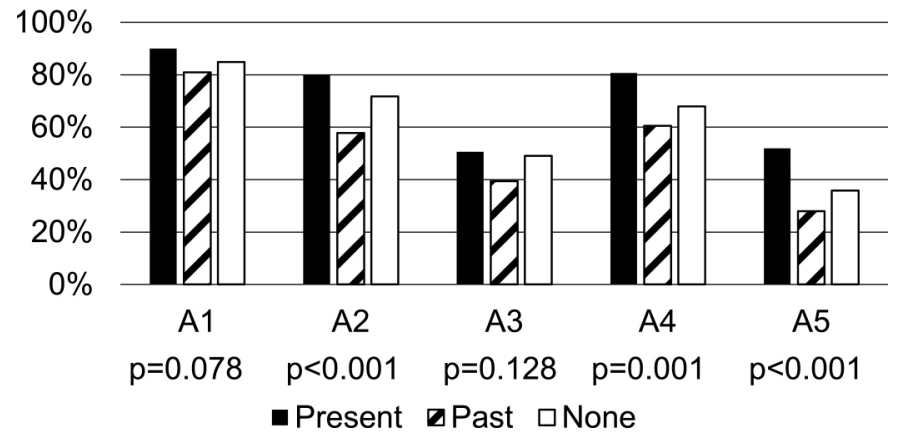

Fig. 5 Explanation after genetic diagnosis of DM1.

A. Comparison among specialities, B. Comparison among facilities, C. Comparison between facitiities joining and not joining to the National Liaison Council for Clinical Sections of Medical Genetics (NLCCSMG), D. Comparison among experience of DM1.

A1. Explain about potential risk of onset and progression of motor dysfunction.

A2. Explain about potential risk of multiple organs complications.

A3. Explain about potential risk for sudden death.

A4. Explain the social systems that are applicable, such as measures against intractable diseases and welfare services for the persons with disabilities.

A5. Explain that there is a patient registry (Remudy). 
A

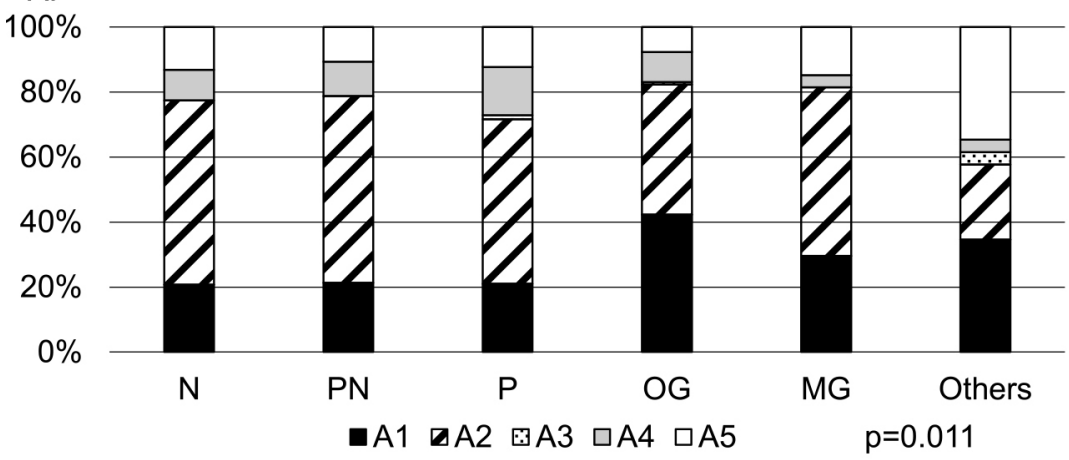

B.

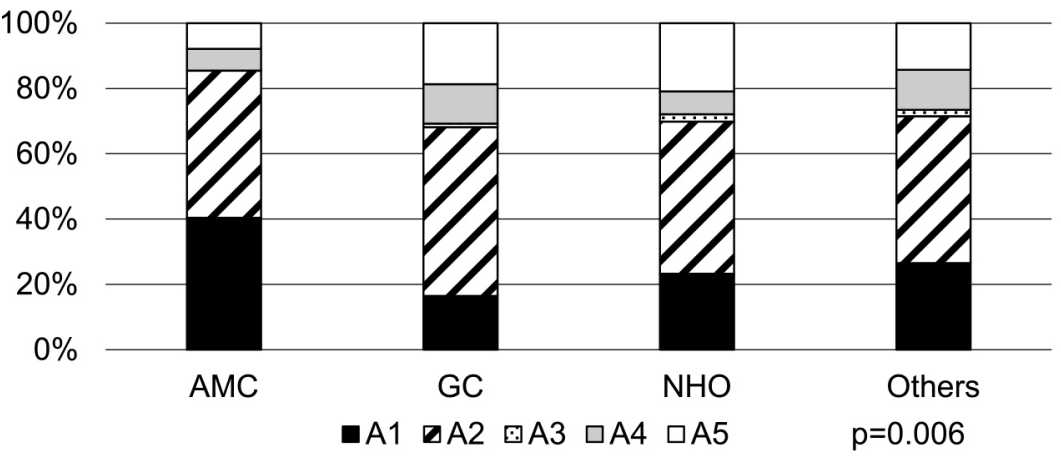

C.

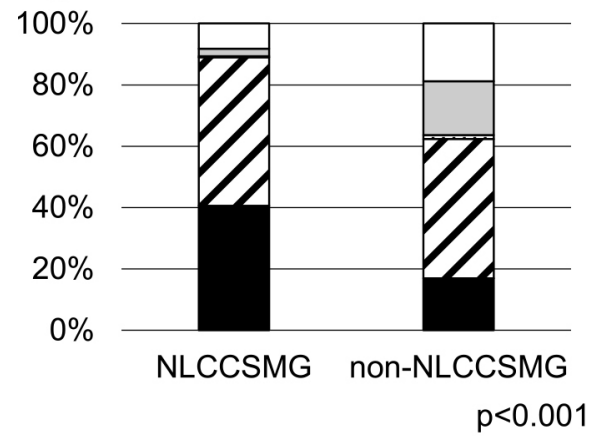

D.

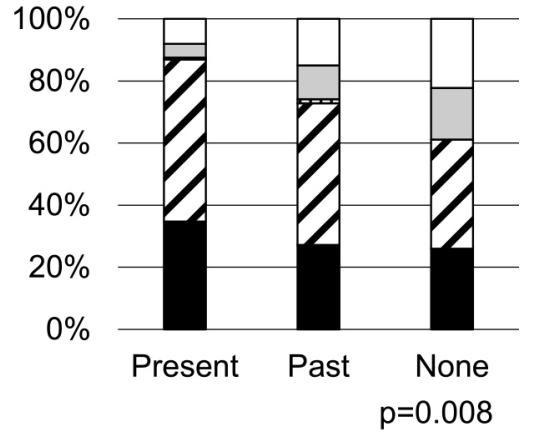

-A1 $\square \mathrm{A} 2 \quad \mathrm{~A} 3 \quad \square \mathrm{A} 4 \square \mathrm{A} 5$

Fig. 6 Attitude for prenatal diagnosis for female patients with DM1.

A. Comparison among specialities, B. Comparison among facilities, C. Comparison between facitiities joining and not joining to NLCCSMG, D. Comparison among experience of DM1.

A1. Both genetic counseling and prenatal diagnosis are performed at my institution.

A2. Genetic counseling is performed at my institution, but prenatal diagnosis is outsourced.

A3. Prenatal diagnosis is performed at my institution, but genetic counseling is outsourced.

A4. Both genetic counseling and prenatal diagnosis are outsourced.

A5. Not dealing with prenatal diagnosis.

明・同意を得て実施される例が多いことから ${ }^{4)}$, CGS による 遺伝学的診療は，合併症受診で DM1 が疑われた場合や，未 発症・未診断患者家族の診断，生殖医療に関わる相談などの 割合が高いと推測される。このような場合，DM1 患者は多臓 器障害であるため, 受診契機となる問題は異なっても，専門 科と連携し集学的医療につなげることが重要である。この点 については，運動機能障害の進行，専門医療機関への定期受 診指導が 8 割以上, 多臓器障害についても約 7 割で説明がな
されており，医療管理につなげる努力がなされていることが 確認できた。一方で, 自由回答では, 妊娠・周産期の診断で は需要困難や子供への対応が優先されること, 中枢神経障害 により医療の必要性が理解されにくいこと, 専門医・紹介先 の不足などで適切な医療につなげることに苦労されている様 子もうかがえた。

今回の調査で回答いただいた CGS の診療経験や診療科, 施 設は様々で, DM1 全体の医療管理を担う N, PN, Present で 


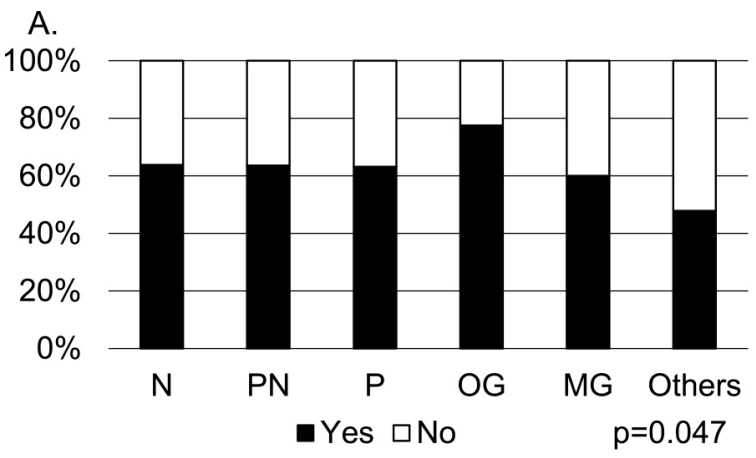

B.

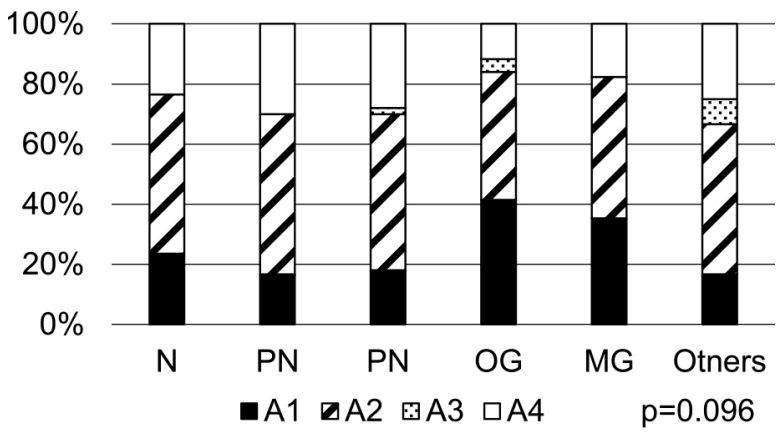

C.

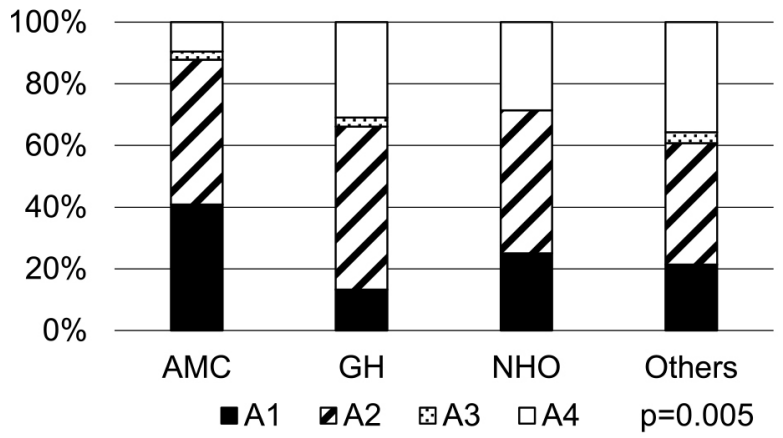

D.

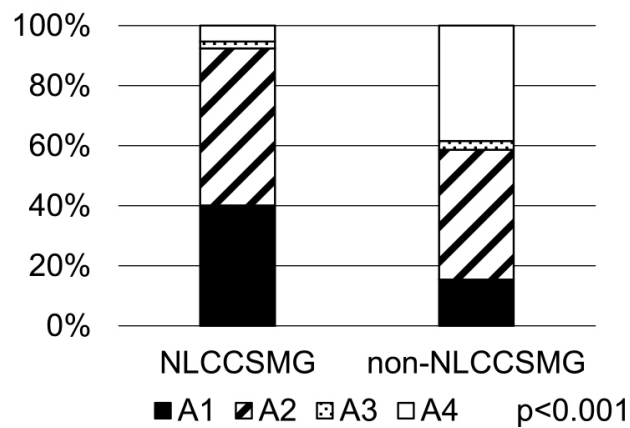

Fig. 7 Attitude for prenatal diagnosis for male patients wih DM1.

A. Are male DM1 patients eligible for prenatal diagnosis? (Comarison among facilities), B-D: (Respondants who answered "Yes" in A.: $\mathrm{N}=222$ ), B. Comparison among specialities, C. Comparison among facilities, D. Comparison between facitiities joining and not joining to NLCCSMG.

A1. Both genetic counseling and prenatal diagnosis are performed at my institution.

A2. Genetic counseling is performed at my institution, but prenatal diagnosis is outsourced.

A3. Prenatal diagnosis is performed at my institution, but genetic counseling is outsourced.

A4. Both genetic counseling and prenatal diagnosis are outsourced. 


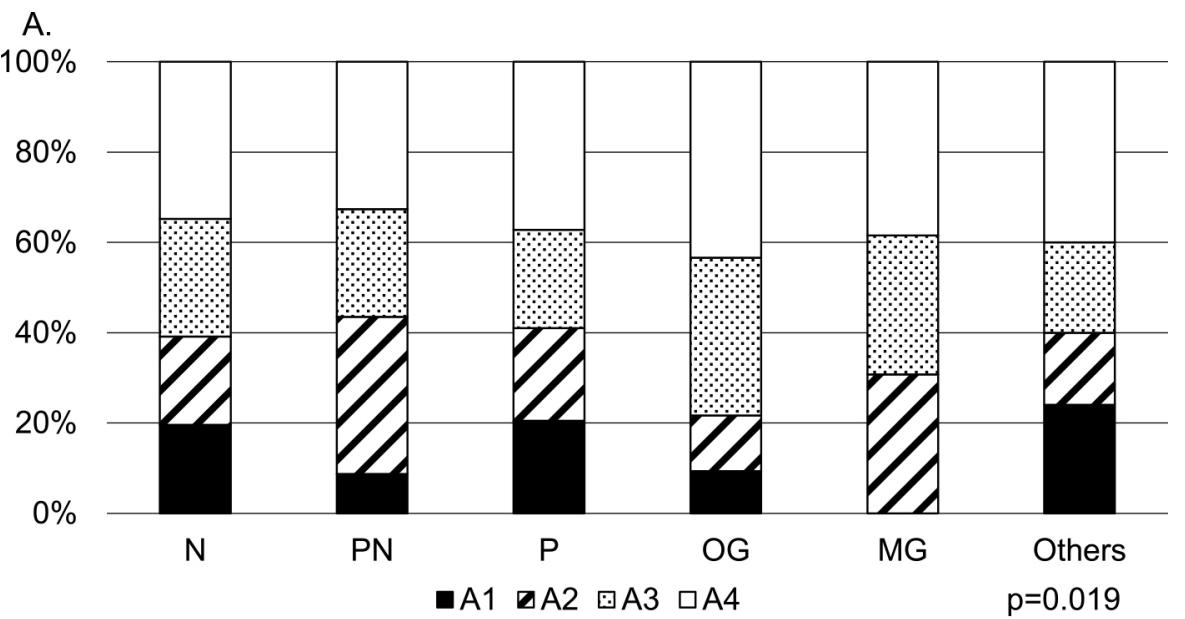

B.

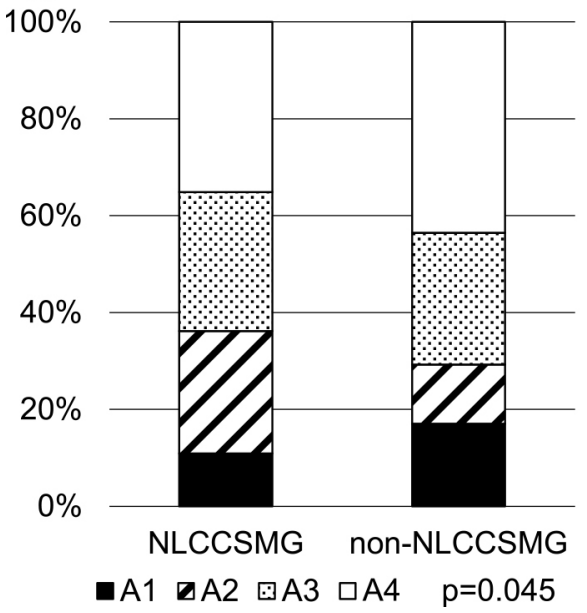

C.

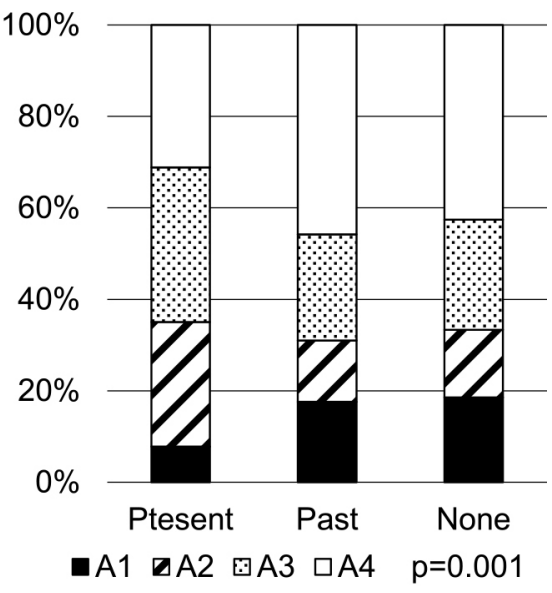

Fig. 8 Opinion for preimplantation genetic diagnosis for patients with DM1.

A. Comparison among specialities, B. Comparison among facilities, C. Comparison among experience of DM1. A1. Preimplantation genetic diagnosis should not be performed.

A2. Preimplantation genetic diagnosis should only be applicable to female patients and not male patients. A3. It should be performed regardless of the sex of the patient, if they wish to undergo the procedure. A4. Criteria for individual ethics review should be relaxed to facilitate the selection of the procedure.

は全般的な説明・対応の割合が高く，社会制度，患者登録や 治療開発を踏まえた説明も高かったのに対し，OGでは生殖 医療に関する説明・対応の割合が高かった，運動機能や合併 症管理, 非発症者の診断について, $\mathrm{PN}$ は $\mathrm{N}$ り積極的で, 子供の健康管理に対する親の関心の高さを反映したものと思 われる。一方，Nや NHO では非発症者の確定診断に消極的 な傾向があった．神経内科領域に多い予防・治療法の無い遺 伝性疾患では発症前診断に慎重なこと, 中枢神経障害のため 確定診断しても適切な医療管理への協力が得にくい経験を反 映したものと思われた

今回の調查結果でめだったのは生殖医療に対して積極的な 意見が多かったことである.PNDについて男性も対象との意 見が全体で $2 / 3$ 以上を占め, PGT が男女とも対象との意見が 3 割弱見られ，基準を緩めるべきとの意見が 4 割弱と，日本 産科婦人科学会の見解 5)6) に比べ積極的な意見が多かった.
自由意見でも積極的意見があり，男性のPND に対応してい るとの回答も多かったことから, 本邦でも男性の PND P PTG が一定数行われている可能性を疑った，本邦での男性 DM1 に打ける PND・PGT の報告は希少で78) 不明な点が多い。こ のため, 実施状況を確認する目的で遺伝子医療部門参加施設 に追加調查を実施した，回答を得た 77 施設の中では，男性 にPND・PGTを実施した施設は無かった（1施設は PGT 申 請中)。しかし, 自由意見では, 男性の PND - PGT に対し積 極的な回答が消極的な回答を上回り，海外や規制に従わない 施設で実施されるよりは十分な対応が可能な施設で透明性を 確保してできるようにすべき，母体の負担や検查による流産・ 人工中絶などの倫理的ハードルから PGT を考虑すべきとの意 見も多かった. 2018 年に行った患者対象調查9) では 25 歳以 上の女性 DM 患者の $25 \%$ が不妊治療を受けており，そのうち 18\%は診断後に不妊治療を受けていた。追加調査とこれらの 
乘離を踏まえると, 遺伝子医療部門非参加施設で PND ・ PGT が行われている可能性は否定しきれない，その場合，中枢神 経障害にも配慮された十分な GC と意思決定支援の元で実施 されているかについて，懸念を感じる，

遺伝性疾患の生殖医療については, 優生思想に関わる倫理 的な課題があり，ガイドライン ${ }^{3)}$ では日本産科婦人科学会の 見解 5)6) に準拠している。一方で，多くの国で男女共にPGT

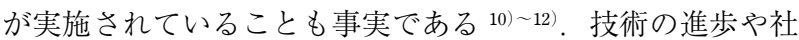
会環境の変化によって, 生殖医療へのコンセンサスも変化す る. 現在，日本産婦人科学会ではPGT に関する倫理審議会を 開催されて抢り，社会変化，診断法・治療法の進歩，海外で の状況などを踏まえて，その適応範囲や重篤性の考え方，透 明性を確保した意思決定支援等について，当事者や多方面か らの意見を集約し議論が進められることを期待する，合わせ て，生殖に関わる自己決定には，CGS に加え遺伝カウンセ ラーなど心理職のサポートを含む専門的体制が必要で, サポー 卜体制の充実や保陘適用範囲の拡大などによる利便性向上も 課題と考元る。

\section{結＼cjkstart語}

全国の CGS, 遺伝子医療部門参加施設を対象に DM の遺伝 学的診療の実態を調查した．DM の抱える課題の多様性を反 映して, 診療経験や診療科の特徴を反映した結果であった。 生殖医療については, 男性患者も含め適切な対応が可能な施 設で選択できる環境を整えるべきとの意見が多かった．

Supplementary data 1: Survey on genetic diagnosis of myotonic dystrophy type 1 .

Supplementary data 2: Survey on prenatal diagnosis and preimplantation genetic diagnosis of dystrophia myotonica type 1 (DM1).

Supplementary data 3: Profile of myotonic dystrophy type 1 experience in each specialty of respondents.

Supplementary data 4: Surveyed institutes.

謝辞：本調査にご協力いただいた臨床遺伝専門医制度委員会, 全国遺 伝子医療部門連絡会議ならびにご回答いただいた全ての先生方, ご施 設に深謝します．本調査は厚労科研「筋ジストロフィーの標準的医療 普及のための調查研究」班にて実施しました.
※著者全員に本論文に関連し，開示すべきCOI 状態にある企業， 組織，団体はいずれも有りません。

\section{文献}

1) Harper PS, van Engelen B, Eymard B, et al. Myotonic dystrophy—present management future therapy-. New York: Oxford University Press; 2004.

2) Takahashi MP, Matsumura T. Myotonic dystrophy-disease mechanism, current management and therapeutic development-. Singapore: Springer; 2018.

3）筋強直性ジストロフィー診療ガイドライン作成委員会. 筋強 直性ジストロフィー診療ガイドライン 2020. 東京：南江堂； 2020.

4）松村剛, 高田博仁, 石垣景子ら. 本邦における筋強直性ジス トロフィーの診療実態調査一専門医対象全国調査一. 臨床神 経 2020:60:120-129.

5）日本産科婦人科学会. 出生前に行われる遺伝学的検査および 診断に関する見解. 日本；2013.

6）日本産科婦人科学会.「着床前診断」に関する見解. 日本;2019.

7）山崎友美, 兵頭麻希, 占部 智ら。筋強直性ジストロフィー の出生前遺伝カウンセリング 7 事例の検討. 日本周産期・新 生児医学会雑誌 2018;54:802-808.

8) Senba H, Sueoka K, Sato S, et al. The impact of parental unaffected allele combination on the diagnostic outcome in the preimplantation genetic testing for myotonic dystrophy type 1 in Japanese ancestry. Reprod Med Biol 2020;19:265-269.

9）高橋正紀，山本理紗，久保田智哉ら。本邦に扮ける筋強直性 ジストロフィーの患者実態調査 患者対象全国調査. 臨床神 経 2020;60:130-136.

10) Kakourou G, Dhanjal S, Mamas $T$, et al. Preimplantation genetic diagnosis for myotonic dystrophy type 1 in the UK. Neuromuscul Disord 2008;18:131-136.

11) De Rademaeker $M$, Verpoest $W$, De Rycke $M$, et al. Preimplantation genetic diagnosis for myotonic dystrophy type 1: upon request to child. Eur J Hum Genet 2009;17:1403-1410.

12) Fernandez RM, Lozano-Arana MD, Sanchez B, et al. Preimplantation genetic diagnosis for myotonic dystrophy type 1 and analysis of the effect of the disease on the reproductive outcome of the affected female patients. Biomed Res Int 2017;2017:9165363. 


\title{
Abstract \\ Questionnaire surveys of clinical genetic specialists on the medical genetics for patients with myotonic dystrophy type 1
}

\author{
Tsuyoshi Matsumura, Ph.D., M.D. ${ }^{1)}$, Yoshika Akizawa, Ph.D., M.D. ${ }^{2)}$, Keiko Ishigaki, Ph.D., M.D. ${ }^{3)}$, \\ Masanori P. Takahashi, Ph.D., M.D. ${ }^{4)}$ \\ 1) Department of Neurology, National Hospital Organization Osaka Toneyama Medical Center \\ ${ }^{2)}$ Department of Obstetrics and Gynecology, Tokyo Women's Medical University \\ 3) Department of Pediatrics, Tokyo Women's University \\ 4) Department of Functional Diagnostic Science, Osaka University Graduate School of Medicine
}

We conducted nationwide questionnaire surveys of medical genetics for patients with myotonic dystrophy type 1 to certified medical geneticists. Explanations about the patient's problems were influenced by geneticist's specialties and central nervous system disorders. Many geneticists answered that male patients are also eligible for prenatal/ preimplantation genetic diagnosis, and they perform prenatal genetic diagnosis for men if asked. About $40 \%$ of respondents answered that criteria for preimplantation genetic diagnosis should be relaxed. Thus, we investigated the implementation status of prenatal/preimplantation genetic diagnosis at the participating facilities of the national liaison council for clinical sections of medical genetics. No facility had an experience of prenatal/preimplantation genetic diagnosis for male patients. Still, one facility was applying for preimplantation genetic diagnosis. The social consensus of reproductive medicine is influenced by technological progress and historical background. It is essential to eliminate the eugenic's idea and form a social consensus through sufficient discussions with participants from many areas, including the patients and their families.

(Rinsho Shinkeigaku (Clin Neurol) 2021;00:000-000)

Key words: myotonic dystrophy type 1 , medical genetics, clinical genetic specialist, prenatal diagnosis, preimplantation genetic testing 